\title{
Use of alternative substrates in production of tomato seedlings
}

\author{
Hiago Felipe Lopes de Farias, Fernando Ribeiro Teles de Camargo, Isneider Luiz Silva*, Sueli \\ Martins de Freitas Alves, Caroline Xavier dos Santos and Elaine de Fátima Miranda Freitas
}

\author{
Universidade Estadual de Goiás-UEG, Anápolis, Goiás, Brazil.
}

Received 10 November, 2017; Accepted 21 December, 2017

\begin{abstract}
Tomato is one of the most produced vegetables in the whole Brazilian territory, also presenting great income to the family producer. The use of organic or alternative substrates has grown, since its acquisition by the producer is easy. Aiming at these factors, the objective of this work was to evaluate the production of three cultivars, Santa Clara, Santa Cruz Kada Gigante and Santa Adélia tomatoes in seven types of substrates formulated with humus and added bovine manure, chicken manure and carbonized rice husk, thus forming a randomized block design in factorial scheme $7 \times 3$. The seeds were sown in styrofoam trays and placed in a greenhouse at Emater-GO experimental station, in the city of Anápolis. Some analyses were carried out to verify the quality of seedlings. The analysis of variance was not significant for the cultivar $\times$ substrate interaction, so the analyses proceeded in isolation. The cultivars Santa Clara and Santa Cruz Kada Gigante were superior to cultivating Santa Adélia in all tests. The substrates that contained chicken manure composition were the ones that presented the best results in all analyses.
\end{abstract}

Key words: Bovine manure, chicken manure, cultivars, humus.

\section{INTRODUCTION}

Tomato (Solanum lycopersicum) is among the main vegetables consumed in Brazil, both fresh and processed, being the most economically important vegetable (Soares et al., 2012). The production of vegetables has driven advances in production techniques that lead to quality seedlings with reduced costs and higher financial returns (Sediyama et al., 2014).

According to Oviedo (2007), the success of tomato production depends on the high quality of the seedling, being an essential factor, since the initial condition of the plant influences the emergence of seedlings, early production, total production and fruit size. This production is highly dependent on the use of inputs to which the substrate has stood out in importance, due to its wide use in the production of seedlings.

A good substrate is one that provides good moisture conditions, nutrient and water availability, macro and microporosity, cation exchange capacity, good root aggregation and uniformity (Teach et al., 2011; Costa et al., 2015). Several are the materials that can be used as

*Corresponding author. E-mail: Isneider.luiz@hotmail.com.

Author(s) agree that this article remain permanently open access under the terms of the Creative Commons Attribution License 4.0 International License 
substrate. These materials should provide adequate development of the seedlings, allowing good formation of the root system and aerial part of the plant (Trigueiro and Guerrini, 2014).

There is no substrate considered to be ideal, each has its advantages and disadvantages, so its choice depends on the characteristics of the crop and the cost to purchase. Therefore, it is necessary to test different substrates or mixtures of substrates for each oleraceous species (Garay et al., 2014).

The use of organic and/or alternative fertilizers makes it possible to provide a balanced supply of nutrients to the plants, decreases their apparent density, improves their structure and the possibility of root penetration into the substrate, and is more available for use by some family farmers (Cerqueira et al., 2015).

Among the materials frequently used as substrate are: earthworm humus (Oliveira et al., 2013), chicken litter (Brugnara, 2014), bovine manure (Gonçalves et al., 2014), and charred rice (husk et al., 2013).

Tomato cultivation may be more of an income option for family agriculture, because it uses labor intensively and generates higher returns per area of exploitation than annual crops (Costa el al., 2013). The production of alternative substrates becomes an important step in the process of production of seedlings in small properties and reducing production costs.

In view of the aforementioned, the objective of the present study is to evaluate the quality of tomato seedlings production cultivated in seven types of alternative substrates.

\section{MATERIALS AND METHODS}

The experiment was conducted at the Emater Experimental Station in Anápolis, GO, whose geographic coordinates are $16^{\circ} 22$ '22 "south latitude and $48^{\circ} 53^{\prime} 08^{\prime \prime}$ west longitude and 1,012 $\mathrm{m}$ altitude. The climate of the region according to the Köppen classification is Aw type, with dry winter and hot and rainy summers (Pereira et al., 2002).

The experimental design was completely randomized, in a $7 \times 3$ factorial scheme, with four replications. The substrates comprised of: S1 control (100\% humus), S2 (50\% humus $+50 \%$ bovine manure), S3 (50\% humus + 50\% chicken manure), S4 (50\% humus $+25 \%$ chicken manure $+25 \%$ bovine manure), S5 (50\% humus + $25 \%$ chicken manure $+25 \%$ charcoal rice husk), S6 (50\% humus + $25 \%$ bovine manure + carbonized rice husk $25 \%)$, and $\mathrm{S7}(50 \%$ humus $+50 \%$ carbonized rice husk). And for three types of tomato cultivars: C1 (Santa Clara 5800), C2 (Santa Cruz Kada Gigante), and C3 (Santa Adélia).

Seeding was performed by placing two seeds in the center of each cell of the tray, at a depth of $0.5 \mathrm{~cm}$. Trays of expanded polyethylene (styrofoam) with a volume of $12.39 \mathrm{~cm}^{3}$ were used, the dimensions of each cell being $6 \times 5 \mathrm{~cm}$, totaling 200 cells.

After sowing, the trays were placed at $0.20 \mathrm{~m}$ from the soil to facilitate the drainage of excess irrigation water. The irrigation system used was the micro-sprinkler, where two irrigations were done daily, the first in the morning and the second in the afternoon.

The experiment was conducted in a protected arc-type environment with the following internal dimensions: $6.0 \mathrm{~m}$ in length and $4.0 \mathrm{~m}$ in width (total area of $24.0 \mathrm{~m}^{2}$ ) and $3 \mathrm{~m}$ in height, oriented in the East-West direction, protected with polypropylene mesh with $65 \%$ shading, on all sides of the metal structure (top and sides).

The thinning was performed 11 days after sowing (DAS) leaving the most vigorous seedling per cell, in which the plots were constituted by 10 seedlings. For the evaluations, eight seedlings per plot were used, and the sides of the trays were considered border.

At 31 days after sowing, the following characteristics were evaluated: number of leaves (NL), count of the fully developed definitive leaves; seedling height $(\mathrm{SH})$, determined with ruler graduated in $\mathrm{cm}$, with the seedlings still in the tray, measuring from the base of the stem to the apex of the last leaf; stem diameter (SD) obtained with a digital caliper $(\mathrm{mm})$ by measuring the diameter of the seedling considering a change in $\mathrm{cm}$ above the neck; root length $(R L)$ determined by measuring the roots from the base of the seedling to its end, with a ruler graduated in $\mathrm{cm}$.

To determine fresh shoot mass (MFPA) and roots (MFR) were obtained by separating the seedlings in aerial part and roots. Afterwards, they were washed in running water, the parts were placed in bags of Kraft paper duly identified according to the treatment and taken for drying in an oven with forced air circulation, at a constant temperature of $70^{\circ} \mathrm{C}$, for $72 \mathrm{~h}$, and then weighed in an analytical balance with a precision of $0.001 \mathrm{~g}$, for the determination of the dry masses of the area (MSPA) and roots (MSR).

For the calculation of the development quality index (IQD), the methodology of Dickson et al. (1960), considering the dry mass of shoots, roots and total dry mass, height and diameter of the lap of the seedlings, using the following equation:

$$
\mathrm{IQD}=\frac{\mathrm{PMST}}{\left(\frac{\mathrm{AP}}{\mathrm{DC}}\right)+\left(\frac{\mathrm{PMSPA}}{\mathrm{PMSR}}\right)}
$$

where IQD = Dickson development index; MST = total dry mass $(\mathrm{g})$; $\mathrm{AP}=$ plant height $(\mathrm{cm}) ; \mathrm{DC}=$ lap diameter $(\mathrm{cm}) ; \mathrm{PMSPA}=$ dry weight of aerial part $(\mathrm{g})$; and PMSRA = root dry mass weight $(\mathrm{g})$.

The obtained data were submitted for analysis of variance by the $\mathrm{F}$ test at $5 \%$ of probability and when significant means comparison test was done-Scott Knott at $5 \%$ of probability. For the variance homogeneity test, Bartlett test and ASSISTAT 7.7 Software were used (Silva and Azevedo, 2016) and the SISVAR Software (Ferreira, 2014) was used for the statistical analyses.

\section{RESULTS AND DISCUSSION}

The different types of substrate and the different cultivars were significant by the $F$ test $(p<0.05)$, different from the Scott-Knott test $(p<0.05)$ for all variables studied. For the interaction between the factors, $F$ test $(p<0.05)$ was not significant for all the analyses that were done, showing that their relation does not interfere in the production of tomato seedlings.

It can be observed that the Santa Clara and Santa Cruz tomato cultivars did not differ among all the variables in the study, presenting the best results for the same, the same was not observed in the cultivar Santa Adélia. The values found for the Santa Clara and Santa Cruz were close to the variables $(\mathrm{SH}),(\mathrm{SD}),(\mathrm{NL})$ and $(\mathrm{RL})$. These cultivars proved to be the best when expected to produce good seedlings (Table 1). 
Table 1. Values of seedling height (SH), stem diameter (SD), average leaf number (NL) and root length $(R L)$ for the three tomato cultivars.

\begin{tabular}{lcccc}
\hline Cultivate & SH $(\mathbf{c m})$ & SD $(\mathbf{m m})$ & $\mathbf{N L}$ & $\mathbf{R L}(\mathbf{c m})$ \\
\hline Santa Clara & $6.88^{\mathrm{A}}$ & $1.47^{\mathrm{A}}$ & $2.53^{\mathrm{A}}$ & $7.89^{\mathrm{A}}$ \\
Santa Cruz & $6.93^{\mathrm{A}}$ & $1.49^{\mathrm{A}}$ & $2.58^{\mathrm{A}}$ & $7.93^{\mathrm{A}}$ \\
Santa Adélia & $3.20^{\mathrm{B}}$ & $0.97^{\mathrm{B}}$ & $1.34^{\mathrm{B}}$ & $6.88^{\mathrm{B}}$ \\
CV $(\%)$ & 23.45 & 23.25 & 24.87 & 16.52 \\
\hline
\end{tabular}

*Values followed by the same letter do not differ from each other by the Scott-Knott test at the $p<0.05$ level.

Table 2. Values of seedling height (SH), stem diameter (SD), mean leaf number (NL), and root length $(\mathrm{RL})$ for the seven substrates.

\begin{tabular}{ccccc}
\hline Substrate & SH $(\mathbf{c m})$ & SD $(\mathbf{m m})$ & NL & RL $(\mathbf{c m})$ \\
\hline S1 & $3.75^{\mathrm{C}}$ & $0.92^{\mathrm{B}}$ & $1.50^{\mathrm{B}}$ & $7.76^{\mathrm{A}}$ \\
S2 & $5.65^{\mathrm{B}}$ & $1.35^{\mathrm{A}}$ & $2.28^{\mathrm{A}}$ & $6.59^{\mathrm{B}}$ \\
S3 & $7.11^{\mathrm{A}}$ & $1.58^{\mathrm{A}}$ & $2.72^{\mathrm{A}}$ & $8.61^{\mathrm{A}}$ \\
S4 & $6.77^{\mathrm{A}}$ & $1.52^{\mathrm{A}}$ & $2.42^{\mathrm{A}}$ & $7.63^{\mathrm{A}}$ \\
S5 & $6.62^{\mathrm{A}}$ & $1.46^{\mathrm{A}}$ & $2.43^{\mathrm{A}}$ & $7.64^{\mathrm{A}}$ \\
S6 & $4.32^{\mathrm{C}}$ & $1.07^{\mathrm{B}}$ & $1.76^{\mathrm{B}}$ & $7.16^{\mathrm{A}}$ \\
S7 & $5.44^{\mathrm{B}}$ & $1.27^{\mathrm{A}}$ & $1.97^{\mathrm{B}}$ & $7.59^{\mathrm{A}}$ \\
\hline
\end{tabular}

*Values followed by the same letter do not differ from each other by the Scott-Knott test at the $p<0.05$ level. S1 ( $100 \%$ humus), S2 (50\% humus $+50 \%$ bovine manure), S3 (50\% humus $+50 \%$ chicken manure), S4 ( $50 \%$ humus $+25 \%$ chicken manure $+25 \%$ bovine manure), S5 (50\% humus $+25 \%$ chicken manure $+25 \%$ carbonized rice husk), S6 (50\% humus $+25 \%$ bovine manure $+25 \%$ carbonized rice husk) and S7 (50\% humus $+50 \%$ carbonized rice husk).

Silva et al. (2012) and Cerqueira et al. (2015), when working with production of tomato seedlings of the cultivars Santa Clara and Santa Cruz, respectively, found similar values for height, stem diameter, and average number of leaves, which corroborate this study.

In Table 2, the types of combinations of the substrates that were used in this study influenced the production of tomato seedlings.

For the height variable, it was observed that the substrates S3, S4 and S5, obtained the highest averages when compared with other combinations. The substrate that had only humus was the one that presented the worst result for height. The highest height was found for the substrate S3 that presented seedlings with $7.11 \mathrm{~cm}$ of height.

For the diameter, a higher number of substrates presented equal means, in addition to S3, S4, and S5, which obtained values between 1.46 and $1.58 \mathrm{~cm}$, the substrates S2 and S7 also presented the same averages statistically. Regarding the number of leaves, the substrate combinations S1, S6 and S7 were the ones with the worst means. In this variable, the highest average found was for the combination of substrate S3, with an average number of 2.72 leaves.

For the root length, it can be seen that only the substrates S2 showed below the other substrates, with a mean of $6.59 \mathrm{~cm}$ of root length. All other combinations of substrates were statistically the same, but the substrate S3 stood out from the others presenting the highest average for the root length.

Some works with production of tomato seedlings also found that the addition of chicken litter and bovine manure to the substrate, promoted an increase in the quality of the seedlings.

Since the chicken litter has one of the highest levels of nitrogen found in its composition, this is the nutrient that is most required throughout the plant formation phase, especially in the initial period (Silva junior et al., 2014; Santos et al., 2015). Brugnara et al. (2014), when analyzing the quality production of passion fruit seedlings, found that the higher addition of chicken litter on the substrates leads to a higher quality of seedlings.

As already seen from the other analyses, the Santa Clara and Santa Cruz tomato cultivars did not differ statistically (Table 3 ), presenting the highest averages in all the evaluated criteria, being these superior to Santa Adélia.

A good porosity allows the movement of water and air in the substrate, favoring the germination, favoring the increase in the fresh masses of the aerial part, of the root, and their respective dry masses, and presenting good quality development index seedlings. 
Table 3. Fresh air mass values (MFA), fresh root mass (MFR), dry mass area (MSA) and root dry mass (MSR), development quality index (IQD), for the three tomato cultivars.

\begin{tabular}{lccccc}
\hline Cultivate & MFA (g) & MFR (g) & MSA (g) & MSR (g) & IQD \\
\hline Santa Clara & $0.65^{\mathrm{A}}$ & $0.61^{\mathrm{A}}$ & $0.35^{\mathrm{A}}$ & $0.31^{\mathrm{A}}$ & $0.34^{\mathrm{A}}$ \\
Santa Cruz & $0.71^{\mathrm{A}}$ & $0.63^{\mathrm{A}}$ & $0.37^{\mathrm{A}}$ & $0.28^{\mathrm{A}}$ & $0.37^{\mathrm{A}}$ \\
Santa Adélia & $0.51^{\mathrm{B}}$ & $0.51^{\mathrm{B}}$ & $0.15^{\mathrm{B}}$ & $0.18^{\mathrm{B}}$ & $0.15^{\mathrm{B}}$ \\
\hline
\end{tabular}

*Values followed by the same letter do not differ from one another by the Scott-Knott test, at the level of $\mathrm{p}<0.05$.

Table 4. Fresh air mass values (MFA), fresh root mass (MFR), dry mass area (MSA) and root dry mass (MSR) development quality index (IQD), for the seven substrates.

\begin{tabular}{cccccc}
\hline Substrate & MFA (g) & MFR $(\mathbf{g})$ & MSA $(\mathbf{g})$ & MSR $(\mathbf{g})$ & IQD \\
\hline S1 & $0.42^{\mathrm{B}}$ & $0.46^{\mathrm{B}}$ & $0.12^{\mathrm{B}}$ & $0.17^{\mathrm{B}}$ & $0.12^{\mathrm{B}}$ \\
S2 & $0.63^{\mathrm{A}}$ & $0.49^{\mathrm{B}}$ & $0.30^{\mathrm{A}}$ & $0.19^{\mathrm{B}}$ & $0.30^{\mathrm{A}}$ \\
S3 & $0.80^{\mathrm{A}}$ & $0.72^{\mathrm{A}}$ & $0.47^{\mathrm{A}}$ & $0.39^{\mathrm{A}}$ & $0.47^{\mathrm{A}}$ \\
S4 & $0.70^{\mathrm{A}}$ & $0.70^{\mathrm{A}}$ & $0.35^{\mathrm{A}}$ & $0.33^{\mathrm{A}}$ & $0.35^{\mathrm{A}}$ \\
S5 & $0.70^{\mathrm{A}}$ & $0.69^{\mathrm{A}}$ & $0.36^{\mathrm{A}}$ & $0.34^{\mathrm{A}}$ & $0.36^{\mathrm{A}}$ \\
S6 & $0.58^{\mathrm{B}}$ & $0.56^{\mathrm{B}}$ & $0.17^{\mathrm{B}}$ & $0.24^{\mathrm{B}}$ & $0.17^{\mathrm{B}}$ \\
S7 & $0.54^{\mathrm{B}}$ & $0.46^{\mathrm{B}}$ & $0.24^{\mathrm{B}}$ & $0.15^{\mathrm{B}}$ & $0.24^{\mathrm{B}}$ \\
\hline
\end{tabular}

*Values followed by the same letter do not differ from each other by the Scott-Knott test at the p<0.05 level. S1 (100\% humus), S2 (50\% humus $+50 \%$ bovine manure), S3 (50\% humus $+50 \%$ chicken manure), S4 $(50 \%$ humus $+25 \%$ chicken manure $+25 \%$ bovine manure), S5 (50\% humus $+25 \%$ chicken manure $+25 \%$ carbonized rice husk), S6 $(50 \%$ humus $+25 \%$ bovine manure $+25 \%$ carbonized rice husk) and S7 ( $50 \%$ humus $+50 \%$ carbonized rice husk).

For all the substrates under study (Table 4), the averages were statistically the same for the substrate S2, S3, S4, and S5, except for the studied variable of fresh root mass, where the substrate S2 presented a lower average in relation to the others. Evaluating the production of fresh matter of the aerial part of the root and their respective dry masses, it was verified that the substrates that contained addition of chicken manure and bovine manure provided a better balance between the growth of the aerial part and the roots, forming seedlings with the vigorous root system, associated with greater leaf development, stem diameter, and seedling height.

Costa et al. (2015) verified when working with seedlings of cherry tomatoes in different types of substrates, that the ones that contained chicken bedding were the ones that presented the highest averages in relation to the quality index of seedlings, dry and fresh matter of roots and compared to other types of substrate formulation.

Silva et al. (2012) evaluating the addition of carbonized rice husk on different substrates for the production of tomato cv. Santa Clara observed a quadratic reduction of shoot mass and root mass.

This fact explains that the seedlings produced lower dry mass with the addition of charcoal rice husk on substrates S6 and S7.

The values of fresh and dry mass of seedlings are a criterion for demonstrating how much a seedling has absorbed the nutrients and water that are present in this substrate, thus, the more nutritious the medium in which the seedlings are, the more they will present a greater weight in its mass (Isah et al., 2014).

According to Costa et al. (2011), Dickson quality index serves as an indicator of the quality of seedlings, involving several parameters, such as seedling height, stem diameter, aerial and root dry mass and total dry mass.

The quality index of tomato seedlings presented values between 0.12 and 0.47 . For the substrates S2, S3, S4 and S5 obtained the highest values of quality, not differing between them, they were not observed in the other substrates under study.

In tomato seedlings, Cerqueira et al. (2015), studying different alternative substrates, observed that the quality values of the seedlings ranged from 0.0037 to 0.0073 , which was not observed in this study.

When analyzing all the variables in question, it can be observed that all the substrates that contained the chicken manure in its composition, presented the best results. Thus, the addition of any other type of compound to the substrates will not have a significant effect on the production of seedlings, since the addition of compounds on substrates will increase its final cost.

\section{Conclusions}

The Santa Clara and Santa Cruz cultivars perform better 
in all variables studied. The use of humus as a base for alternative substrates, with the addition of compounds such as chicken litter and bovine manure in the appropriate proportions (S3, S4, and S5), can produce seedlings with a high quality index, making feasible the use of these compounds in the formulation of substrates for tomatoes.

\section{CONFLICT OF INTERESTS}

The authors have not declared any conflict of interests.

\section{REFERENCES}

Brugnara EC, Nesi CN, Verona LAF (2014). Cama de aviário e composto de dejetos suínos em substratos para mudas de maracujazeiro-amarelo. Científica 42:242-251.

Cerqueira FB, Freitas GA, Maciel CdeJ, Carneiro JSS, Leite RC (2015). Produção de mudas de tomate cv. santa cruz em diferentes substratos. J. Bioenergy Food Sci. 2:39-45.

Costa LAM, Costa MSSM, Pereira DC, Bernardi FH, Sílvia M (2013). Avaliação de substratos para a produção de mudas de tomate $\mathrm{e}$ pepino. Rev. Ceres 60:675-682.

Costa E, Santo TLE, Silva AP, Silva LE, Oliveira LC, Benett CGS, Benett KSS (2015). Ambientes e substratos na formação de mudas e produção de frutos de cultivares de tomate cereja. Hortic. Bras. 33:110-118.

Dickson A, Leaf AL, Hosner JF (1960). Quality appraisal of white spruce and white pine seedling stock in nurseries. The For. Chron. 36(1):1013.

Ferreira DF (2014). Sisvar: a Guide for its Bootstrap procedures in multiple comparisons. Ciência e Agrotecnologia 38(2):109-112.

Garay CRE, Bogarin NBG, Oviedo VRS (2014). Producción de mudas de tomate en el sistema flotante. Investigación Agraria 16:129-135.

Gonçalves EO, Petri GM, Caldeira MVW, Damalso TT, Silva AG (2014). Crescimento de mudas de Ateleia glazioviana em substratos contendo diferentes materiais orgânicos. Floresta e Ambiente 21:339-348.

Isah AS, Amans EB, Odion EC, Yusuf AA (2014). Growth Rate and Yield of Two Tomato Varieties (Lycopersicon esculentum Mill) under Green Manure and NPK Fertilizer Rate Samaru Northern Guinea Savanna. Int. J. Agron. Article ID 932759, 8pp.

Oliveira JR, Xavier FB, Duarte NF (2013). Húmus de minhoca associado a composto orgânico para a produção de mudas de tomate. Rev. Agrogeoambiental 5:79-86.

Oviedo VRS (2007). Produção de tomate em função da idade da muda e volume do recipiente. 80p. Tese Doutorado. Escola Superior de agricultura Luiz de Queiroz, Piracicaba - SP, Brasil.
Santos ACMdos, Carneiro JSdaS, Ferreira Junior JM, Silva MCA da, Silva RR da (2015). Produção de mudas de tomateiro cv. Drica sob substratos alternativos. Agropecuária Científica no Semiárido 11: 0112.

Sediyama MAN, Santos MR, Vidigal SM, Pinto CLO, Jacob LL (2014). Nutrição e produtividade de plantas de pimentão colorido, adubadas com biofertilizante de suíno. Agriambi 18:588-594.

Silva FAS, Azevedo CAV (2016). The Assistat Software Version 7.7 and its use in the analysis of experimental data. Afr. J. Agric. Res. 11:3733-3740.

Silva Júnior JV, Beckmann MZ, Silva LP, Brito LPS, Avelino RC, Cavalcante IHL (2014). Aproveitamento de materiais alternativos na produção de mudas de tomateiro sob adubação foliar. Rev. Ciênc. Agron. 45:528-536.

Silva RR, Rodrigues LU, Freitas GA, Melo AV, Nascimento IR, D'Andréa AF (2012). Influência de casca de arroz carbonizada em diferentes substratos na qualidade de mudas de tomateiro. Rev. Bras. de Ciênc. Agrár. 7:803-809.

Soares LAA, Sousa JRM, Brito MEB, SÁ FVS, Silva ECB (2012). Qualidade de frutos de tomateiro em cultivo protegido sob diferentes lâminas de irrigação nas fases fenológicas. Agropecuária Científica no Semiárido 8: 113-117.

Trigueiro RM, Guerrini IA (2014). Utilização de lodo de esgoto na produção de mudas de aroeira pimenteira. Rev. Árvore 38:657-665. 